\title{
In Pursuit of Everyday Creativity
}

\section{Citation}

Amabile, Teresa M. "In Pursuit of Everyday Creativity." Harvard Business School Working Paper, No. 18-002, July 2017.

\section{Permanent link}

http://nrs.harvard.edu/urn-3:HUL.InstRepos:33840634

\section{Terms of Use}

This article was downloaded from Harvard University's DASH repository, and is made available under the terms and conditions applicable to Open Access Policy Articles, as set forth at http:// nrs.harvard.edu/urn-3:HUL.InstRepos:dash.current.terms-of-use\#OAP

\section{Share Your Story}

The Harvard community has made this article openly available.

Please share how this access benefits you. Submit a story.

Accessibility 


$$
\text { H A R V A R D }
$$

\section{In Pursuit of Everyday Creativity}

Teresa M. Amabile

Working Paper 18-002 


\title{
In Pursuit of Everyday Creativity
}

\author{
Teresa M. Amabile
}

Harvard Business School

Working Paper 18-002 not be reproduced without permission of the copyright holder. Copies of working papers are available from the author. 


\title{
In Pursuit of Everyday Creativity
}

\author{
Teresa M. Amabile \\ Harvard Business School \\ tamabile@hbs.edu
}

$617-495-6871$

June 2017

Article accepted for publication in the special $50^{\text {th }}$ anniversary issue of the Journal of Creative Behavior, edited by Ron Beghetto. DOI: 10.1002/jocb.200 


\begin{abstract}
Creativity researchers have long paid careful attention to individual creativity, beginning with studies of well-known geniuses, and expanding to personality, biographical, cognitive, and social-psychological studies of individual creative behavior. Little is known, however, about the everyday psychological experience and associated creative behavior in the life and work of ordinary individuals. Yet evidence is mounting that such individuals can be responsible for important instances of creativity and innovation in the world: open innovation, user innovation, and citizen innovation. Research into this phenomenon could do much to advance the study and practice of creativity.
\end{abstract}




\section{In Pursuit of Everyday Creativity}

The world has long been fascinated by creative individuals - people who produce work that dramatically touches us aesthetically or advances our lives technologically. Sharing this fascination, creativity researchers have long paid careful attention to individual creativity, beginning with studies of well-known geniuses (e.g., Cox, 1926; Galton, 1869). While this tradition has continued (e.g., Gardner, 1993; Gruber, 1982), research topics in recent decades have expanded to encompass personality, biographical, cognitive, and socio-cultural studies of both well-known and lesser-known creative individuals (e.g., MacKinnon, 1965; Simonton, 1975); personality traits associated with creativity in the general population (e.g., Feist, 1998); and social-psychological studies of environmental influences on individual creative behavior (e.g., Amabile, 1996). The creativity literature now holds a rich repository of knowledge about the individual characteristics associated with creativity and the social and culture environments that support or undermine it. But there is much that this literature cannot yet explain about individual creative behavior.

In recent years, a somewhat separate literature has developed on innovation - the implementation of creative ideas in organizations, communities, and societies. Two recent streams of this literature are particularly interesting (see Harhoff \& Lakhani, 2016). The first stream tests and documents approaches to what is often referred to as "open innovation" or "crowd-sourcing” - the use of unaffiliated individuals, outside an organizational context, who have no particular expertise in the focal problem domain - to solve complex problems in science, industrial $\mathrm{R} \& \mathrm{D}$, internet commerce, software 
development, and other real-world settings. For example, one recent study demonstrated that a commercial programming competition platform (TopCoder.com), open to programmers anywhere in the world, yielded solutions to a complex problem in computational biology that were equal in accuracy, and far superior in speed, to the best solutions produced by customized methods in the computational biology field (Lakhani et al., 2013).

The second stream of innovation research particularly relevant to the literature on individual creativity is work on user innovation. Building on the pioneering work of economist Eric von Hippel, this research examines the growing phenomenon whereby companies that produce new goods and services rely on users of those goods and services to come up with and even help develop and implement new ideas (see von Hippel, 1988; 2005). Examples abound. A recent theoretical paper on user entrepreneurship (Shah \& Tripsas, 2016) noted that, in the field of scientific instruments, where the users are generally academic scientists or technicians, user innovations include such breakthroughs as the electron microscope and well-regulated high-voltage power supplies. Indeed, that paper argues that (a) many important innovations are developed by users (such as $76 \%$ of important innovations in scientific instruments and 60\% of innovations in consumer sporting equipment); (b) a large fraction of users innovate (such as $38 \%$ of consumer sports enthusiasts); and (c) users innovate over a wide variety of product domains (including automobiles, astronomy equipment, and medical devices, in addition to the domains already mentioned).

A third stream of research is just beginning to emerge from a variety of disciplines: Work on innovation that results from individuals and teams solving problems 
that face their communities or societies. For example, one recent qualitative study of Dutch local governments found considerable evidence of civil service employees implementing creative solutions to solve local problems, such as finding "tailor-made solutions for citizens” within the context of existing rules and regulations (Kruyen \& van Genugten, in press). Another qualitative study documented and analyzed instances of citizens who generated and implemented creative solutions to a myriad of problems following the devastating earthquakes of 2010-2011 in Christchurch, New Zealand solutions as diverse as a shopping complex in upcycled shipping containers, a bar in a bus, and an automated outdoor dance floor on vacant land (Cameron-Agnew, Montgomery, Steward, \& Moore, 2017).

As rich as the creativity literature is on questions about individual creativity, it contains few answers this fundamental question: When ordinary people undertake creative endeavors in their work or their non-work lives, what is the nature of their everyday psychological experiences, and how do those experiences affect creative outcomes? My collaborators and I conducted an experience-sampling study several years ago that yielded some tantalizing hints at answers (Amabile et al., 2001; Amabile, Barsade, Mueller \& Staw, 2005; Amabile \& Kramer, 2011a, 2011b; Amabile, Schatzel, Moneta, \& Kramer, 2004; Moneta, Amabile, Schatzel, \& Kramer, 2010). Analyzing nearly 12,000 daily electronic diary entries that we collected from 238 professionals working on 26 projects that called for creativity in seven different companies, we made three central discoveries. First, we found that day-by-day psychological experience emotions, perceptions, and motivations - significantly influences creative performance as indicated by supervisor ratings, peer ratings, and quasi-behavioral measures of creative 
thought; creativity is higher when emotions and perceptions are more positive, and when intrinsic motivation is stronger. Second, we found that, of all the workday events that can lead to positive psychological experience, the single most important is making progress in meaningful work; setbacks have the opposite effect. Finally, and perhaps most importantly for the purposes of this essay, we discovered that individuals trying to be creative in their work not only experience, but can also describe, a rich and wide variety of emotions, perceptions, and motivations that relate to their work and color the quality of their lives in ways that we are only beginning to understand.

Attacking this question is fundamentally important for both the science and the practice of creativity. Increasingly, technology is enabling open innovation, user innovation, and citizen innovation. It seems increasingly likely that products and services resulting from the creative behavior of ordinary individuals may not only become more prevalent than those coming from experts or geniuses in particular domains, it many actually become the most important source of creative breakthroughs. In order to fully understand creativity and what influences it, and in order to confidently prescribe ways in which individuals, organizations, and societies can enhance it, we must undertake studies of creative behavior - and the accompanying psychological states and environmental contexts - in situ, as it is happening. As is obvious in the present issue of the Journal of Creative Behavior, this is only one of the many pathways that creativity studies should take in the coming years. But, I believe, it is one of the most important. 


\section{References}

Amabile, T. M. (1996). Creativity in context. Boulder, CO: Westview Press.

Amabile, T.M., Barsade, S.G., Mueller, J.S. \& Staw, B.M (2005). Affect and Creativity at Work. Administrative Science Quarterly, 50:3, 367-403.

Amabile, T.M. \& Kramer, S.J. (2011a). The Progress Principle: Using Small Wins to Ignite Joy, Engagement, and Creativity at Work. Boston: Harvard Business Review Press.

Amabile, T. M. \& Kramer, S. J. (2011b). Meeting the challenges of a person-centric work psychology. Industrial and Organizational Psychology, 4, 116-121.

Amabile, T.M., Patterson, C., Mueller, J. S., Wojcik , T., Odomirok, P., Marsh, M., \& Kramer, S. (2001). Academic-Practitioner Collaboration in Management Research: A Case of Cross-Profession Collaboration. Academy of Management Journal, 44, 418-431.

Amabile, T.M., Schatzel, E.A., Moneta, G.B. \& Kramer, S.J. (2004). Leader behaviors and the work environment for creativity: Perceived leader support. The Leadership Quarterly, $15: 1,5-32$.

Cameron-Agnew, T., Montgomery, R., Moore, K., \& Stewart, E. J. (2017). Swimming with ideas: What happens to creativity in the wake of a disaster and the waves of pro-social recovery behaviour that follow? Working paper, Lincoln University, New Zealand.

Cox, C. (1926). The early mental traits of three hundred geniuses. Stanford, CA: Stanford University Press.

Feist, G.J. (1998). A meta-analysis of the impact of personality on scientific and artistic creativity. Personality and Social Psychological Review, 2, 290-309.

Galton, F. (1869). Hereditary genius: An inquiry into its laws and consequences. London: Macmillan. 
Gardner, H. (1993). Creating minds. New York: Basic Books.

Gruber, H. E. (1982). Darwin on man. 2nd ed. Chicago: University of Chicago Press.

Harhoff, D. \& Lakhani, K. R. (2016) Revolutionizing innovation: Users, communities, and open innovation. Cambridge, Massachusetts: MIT Press.

Kruyen, P. M. \& van Genugten, M. L. (in press). Creativity in local government: Definition and determinants. Public Administration.

Lakhani, K. R., Boudreau, K. J., Loh, P., Backstrom, L., Baldwin, C., Lonstein, E., Lydon, M., MacCormack, A., Arnaout, R. A., \& Guinan, E. C. (2013). Prize-based contests can provide solutions to computational biology problems. Nature Biotechnology, 31, 108111.

MacKinnon, D. W. (1965). Personality and the realization of creative potential. American Psychologist, 20, 273-281.

Moneta, G. B., Amabile, T., Schatzel, E. A. \& Kramer, S. (2010). Multi-Rater Assessment of Creative Contributions to Team Projects in Organizations. European Journal of Work and Organizational Psychology, 19:2, 150-176.

Shah, S. K. \& Tripsas, M. (2016). When do user-innovators start firms? A theory of user entrepreneurship. In Harhoff, D. \& Lakhani, K. R. (Eds.), Revolutionizing innovation: Users, communities, and open innovation. Cambridge, MA: MIT Press.

Simonton, D, K. (1975). Sociocultural context of individual creativity: A transhistorical timeseries analysis. Journal of Personality and Social Psychology, 32, 1119-1133.

von Hippel, E. (1988). The sources of innovation. New York: Oxford University Press. von Hippel, E. (2005). Democratizing innovation. Cambridge: MIT Press. 